\begin{tabular}{|l|l|l}
\hline \hline Vol. 30(2):181-191 & Ocean and Polar Research & June 2008 \\
\hline
\end{tabular}

\title{
Article
}

\author{
제주도 서쪽 연안에서 음향자원 조사를 이용한 \\ 저층 어군의 시 - 공간 분포 \\ 강돈혁 $^{*} \cdot$ 임양재 ${ }^{2} \cdot$ 이창원 ${ }^{1} \cdot$ 유준택 ${ }^{2} \cdot$ 명정구 ${ }^{1}$ \\ 1한국해양연구원 해양생물자원연구부 \\ (425-600) 경기도 안산시 안산우체국 사서함 29 \\ 2국립수산과학원 제주수산연구소 \\ (690-192) 제주특별자치도 제주시 외도 2동 1928
}

\section{Hydroacoustic Survey of Spatio-Temporal Distribution of Demersal Fish Aggregations Near the West Coast of Jeju Island, Korea}

\author{
Donghyug Kang ${ }^{1 *}$, Yangjae $\mathrm{Im}^{2}$, Changwon Lee ${ }^{1}$, Joontaek Yoo $^{2}$, and Jung-Goo Myoung ${ }^{1}$ \\ ${ }^{1}$ Marine Living Resources Research Department, KORDI \\ Ansan P.O. Box 29, Seoul 425-600, Korea \\ ${ }^{2}$ Jeju Fisheries Research Institute, NFRDI
}

Јејu 690-192, Korea

\begin{abstract}
This study aims at assessment of spatio-temporal distribution of demersal fish aggregations near the west coast of Jeju Island using hydroacoustic survey. A $200 \mathrm{kHz}$ split beam transducer attached to a small towed body was used for all acoustic investigations. The received acoustic data were in situ acoustic target strength (TS, dB) for all pings and nautical area scattering coefficient (NASC, $\mathrm{m}^{2} / \mathrm{mile}^{2}$ ) for 0.1 mile along 12 acoustic transects. Demersal fish aggregations are distributed around the coastal slope having 20 to $30 \mathrm{~m}$ depth throughout all seasons. The concentration is higher during the summer season. With regard spatial distribution, higher demersal fish aggregations have been detected near the West coast of Shinchang and especially near Chagwi-do. Pelagic fish aggregations were higher to the south of Chagwi-do during the spring season. Additionally, standing stock of demersal fish aggregations from the NASC data, TS function, and length-weight function of dominant species was estimated as follows: 3.2 ton $(C V 21.8 \%)$ in December 2006, 17.9 ton (CV 21.6\%) in April 2007, 30.8 ton (CV 17.8\%) in June 2007, and 22.5 ton $(C V 24.2 \%)$ in October 2007. The application of hydroacoustic methods offers a new approach to understanding spatiotemporal structure and estimate the biomass of demersal fish aggregations in the coastal area. And the results can be made up limitations of qualitative analysis through net and diving for fisheries resources survey in coastal area.
\end{abstract}

Key words : coastal region, demersal fish aggregations, hydroacoustic survey, spatio-temporal distribution, west coast of Jeju

\section{1. 서 론}

우리나라 연안 지역에서 수산 자원의 시·공간 분포 특

*Corresponding author. E-mail : dhkang@kordi.re.kr
성 파악을 위한 연구 방법으로는 다양한 어구 어법을 이 용하는 방법과 잠수를 통한 직접 조사 방법이 있으며 많 은 연안 어류의 연구들이 이들 방법으로부터 현존하는 어 류의 종 조성을 파악하는데 초점을 맞추어 왔다(김 등 1999; 허와 안 2000; 명 등 2003; 차 등 2004). 이들 방법 
들은 정성적인 자료 측면에서는 많은 장점이 있지만 채집 면적 및 채집 수 층의 제한성이라는 측면에서 보면 정량 적인 자료 도출에 오차를 만들어 낼 가능성이 크다. 정성 분석에 치우친 두 가지 조사 방법의 문제점을 극복하기 위한 방법의 하나로 최근 수산 분야에 다양하게 적용되고 있는 수산 음향을 이용하는 방법이 대두되고 있다 (MacLennan and Simmonds 1992; Abad et al. 1998).

수중음향을 이용한 수산 자원 조사 방법은 원양 수산 자원의 분포 조사에 광범위하게 사용되고 있으며 최근에 는 연안 조사에까지 확대되고 있다(Simmonds and MacLennan 2005). 수산음향 기법은 연구자의 주관을 배 제시키고 사전에 설정된 음향 조사 정선으로부터 연속적 이며 수 층 전체에 대한 객관적인 자료를 얻을 수 있다. 특히 우점종이 분포하는 해역에서 우점 어류의 음향 표적 강도(acoustic target strength, TS) 특성이 제공된다면 현존 자원량까지 추정이 가능한 방법으로 알려지고 있다(Foote 1987; Hewitt and Demer 1993; Ohshimo 2004).

우리나라에서 수산음향 기법을 이용한 연안 어류 자원 조사는 2001년 통영 해역에서 시작되어 여수 남단의 다도 해 지역까지 확대되고 있으며 주로 어군의 공간 분포에 초점을 두고 계절별로 이루어지고 있다(해양수산부 2002; 해양수산부 2006). 최근에는 동해의 울진 해역과 제주도 연안의 자원 조사 특성 파악에 음향 기법을 일부 적용하 고 있다(해양수산부 2007).

음향 자원 기법이 적용되고 있는 제주도 연안은 섬이 많은 서남해와 달리 해안선 굴곡이 단조로운 지형 구조를 가지고 있다. 이러한 해안선 구조에 의해 제주도 연안은 대마 난류수, 황해 난류수, 중국 대륙 연안수, 황해 저층 냉수 등의 서로 다른 수괴가 계절별로 상호 관계를 갖으 며 매우 복잡한 구조를 보이고 있어, 이로 인한 연안 어류 의 종조성이나 분포 특성이 시기별로 큰 차이를 보이고 있다(Pang et al. 1992; 김과 노 1994).

복잡한 해양 환경의 조건임에도 불구하고 제주 해역에 서 많은 연안 어류의 조사는 다른 연안 조사와 유사하게 자망이나 잠수를 통한 어류의 종 조성이나 다양도 연구에 주안점을 두고 있다(고와 신 1990; 김 등 1999; 차 등 2004). 이러한 조사 방법은 해양 환경의 변화에 의해 다양 하게 형성되는 연안 어류 자원의 시·공간 분포 특성 파 악에 한계를 가지고 있으며, 특히 어류 군집의 수직 분포 특성 파악에 많은 어려움을 주고 있다. 종 조성이나 다양 도 연구에 치우친 연안 자원 조사에 음향 조사 기법은 어 류 군집의 구조 파악 및 시·공간 특성 파악과 더불어 중 요 우점 종으로부터 현존 자원량을 추정하는 새로운 가능 성을 제시할 것이다.

본 연구에서는 수산 음향 기법이 가지는 장점을 이용하 여 다양한 해양 환경 변화에 의해 형성되는 제주도 서쪽
연안 지역의 어류 자원에 대해 저층 부근에 형성되는 어 군을 중심으로 계절별 시·공간 분포 및 수직 분포 특성 을 파악하였다. 부가적으로 음향 조사로부터 얻어진 저층 음향 자료와 삼중자망 및 통발 조사를 통한 저서 우점 어 류의 어획 자료를 이용하여 저층 부근 어류의 현존량을 추정하였다.

\section{2. 재료 및 방법}

\section{조사 지역 및 방법}

음향 조사가 실시된 해역은 제주도 서쪽 연안으로 남북 으로는 신창리 앞에서 고산의 수월봉까지 약 $9.3 \mathrm{~km}$, 육 지로부터 서쪽으로 $3.2 \mathrm{~km}$ 에 이르는 지역이다. 연구 지역 은 2004년부터 해양수산부가 시행하고 있는 제주 바다목 장 조성 해역으로 차귀도, 와도, 죽도 등 3 개의 섬이 존재 하고 있다(해양수산부 2003). 특히 이 지역은 수중 암반이 잘 발달되어 있고 수온이 높아 아열대 해역의 특성을 보 이며, 계절적으로 외해 저층으로부터 용승이 발생하여 수 산 생물이 풍부하고 다양하게 출현하는 해역으로 다양한 수산 생물이 서식하는 자원 생물학적 가치가 높은 해역이 다(방과 김 1993; 이 등 2006).

시 - 공간 분포 및 수직 분포 파악을 위한 계절별 음향 자원 조사는 2006년 12월 21일(동계), 2007년 4월 11일 (춘계), 6월 20일(하계), 10 월 22일(추계)에 걸쳐 각 계절

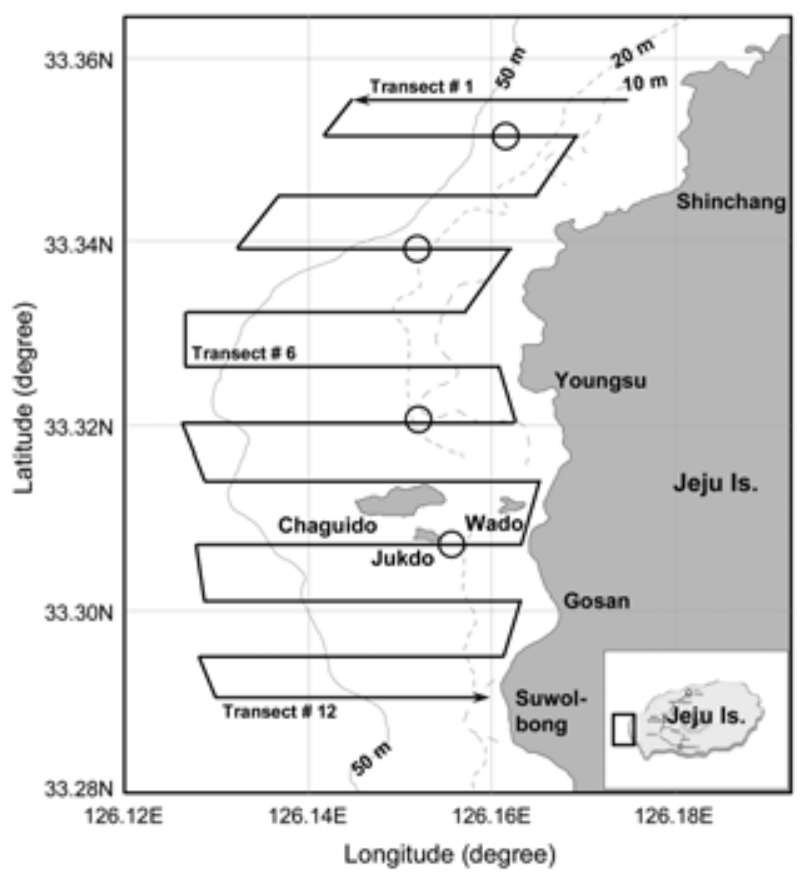

Fig. 1. Study area for acoustic survey of demersal fish aggregations in the western coast of Jeju Island, Korea. The circles represent sampling station for fish catches on October 2007. 
별로 1 회씩 총 4 회에 걸쳐 실시하였고, 어군의 자원량 추 정을 위한 어류 채집은 신창, 용당, 용수, 고산의 4개 해역 에서 2007년 10월에 실시하였다(Fig. 1). 어류 채집은 한 폭의 크기가 가로 $50 \mathrm{~m}$, 세로 $5 \mathrm{~m}$ 인 삼중자망 10 폭(500 $\mathrm{m}$ )을 투승하여 1일 후 양승하였고, 직경 $32 \mathrm{~cm}$, 폭 $60 \mathrm{~cm}$ 의 통발을 각 조사지역에 20개씩 일정한 간격으로 투승하 여 3일 후 양승하였다(해양수산부 2007). 음향 조사는 동-서 방향의 정선에 대해 얕은 곳은 연안의 수심 $5 \mathrm{~m}$, 깊 은 곳은 $90 \mathrm{~m}$ 까지 실시하였다. 음향 조사를 위한 정선 수 는 12 개로 4 회 모두 동일한 정선을 설정하였다. 총 조사 거리는 23 24마일로 정선 사이의 간격이 일정한 평행 정 선(parallel transect) 방식을 적용하였다.

\section{음향 시스템}

음향 어군 조사를 위한 계량어군 탐지기(scientific echosounder)는 시스템 제어부, 센서부 및 예인체로 구성 된 통합 시스템을 사용하였다(Biosonics 2005). 수심이 얕은 연안 조사임을 고려하여 $200 \mathrm{kHz}$ 의 분할빔 음향 센 서를 소형 예인체에 부착하여 선박의 현측에서 예인하였 다. 음향 센서의 안정도는 수심이 얕은 천해에서 해저면 신호 및 어류 탐지 신호의 수신 값에 큰 영향을 주게 된 다. 본 연구에 사용된 음향 센서는 내부에 방위 및 센서 기울기를 측정하는 독립적인 센서를 가지고 있다. 따라서 해저면 신호의 강도와 센서 기울기 자료로부터 예인 속 도를 조절하였으며, 이때 안정된 해저면 신호를 수신하는 예인체의 pitch, roll 허용 각도는 $\pm 7^{\circ}$ 예인 속도는 약 4 노 트였다.

음향 자료 수신을 위한 펄스 주기는 수심이 얕은 천해 역이고 탐지 어군의 분해능을 증가시킬 수 있는 장점을 고려하여 초당 $5 \mathrm{ping}$ 으로 하였다. 음향 자료 처리에 필수 적인 음향 센서의 위치 정보는 조사 주변의 섬과 육지에
근접하여 음향 조사를 실시하므로 기존의 GPS보다 정확 도가 높은 DGPS를 사용하였다. 음향 조사에 사용한 펄스 길이는 수직 분해능을 최대한 증가시키기 위하여 첫 조사 시기인 2006년 12월에는 $0.1 \mathrm{~ms}$ 로 설정하였다. 그러나 12 월에 수신된 개개 어류의 현장 음향 표적 강도(in situ TS, $\mathrm{dB}$ ) 자료를 분석한 결과 낮은 값의 $\mathrm{TS}$ 가 대량으로 수신되 었다. 높은 체고(body height)를 가진 어류의 경우 좁은 분 해능에 의해 복수의 음향 산란체로 인식할 가능성이 있어 이후 조사에서는 개개 어류의 음향 탐지 분해 거리를 $20 \mathrm{~cm}$ 이상으로 증가시키기 위하여 펄스 길이를 0.3-0.5 $\mathrm{ms}$ 로 변경하였다. 4 회에 걸친 음향 조사로부터 층별 어군 의 분포 특성 및 강도를 나타내는 체적 후방산란 강도 $\left(S_{v}\right.$, $\mathrm{dB}$ ) 값과 개개 어류의 현장 음향 표적강도(in situ $\mathrm{TS}, \mathrm{dB}$ ) 값을 저장하였다. 각 시기별 설정한 음향 시스템의 변수들 은 Table 1과 같다.

\section{음향 자료 처리}

조사 지역에서 어류 자원의 시·공간 분포 특성은 계 량어군탐지기로부터 출력되는 체적 산란강도(volume scattering strength, $S_{v}$ ) 자료를 이용하여 분석하였다. $S_{v}$ 자료는 비선형 형태로 인한 이해의 어려움 때문에 최근에 는 선형 개념인 면적으로 표시되는 면적 산란 계수 (Nautical Area Scattering Coefficient, NASC, $\mathrm{m}^{2} / \mathrm{mile}^{2}$ )로 변환하여 사용하고 있다(SonarData 2000). 따라서 본 연 구에서 수신된 모든 어군의 $S_{v}$ 자료는 NASC 형태로 변환 된 값을 이용하였다.

본 연구의 목적인 해저면 부근의 어류 분포를 알기 위 하여 모든 음향 자료에서 표층의 잡음을 제거한 에코그램 을 대상으로 (1) 해저면 해저면 위 $5 \mathrm{~m}$ 수층, (2) 해수면 해저면 위 $5 \mathrm{~m}$ 수층으로 분리되는 2 개의 수층을 구성하 였다(Fig. 2). 분리된 2개의 수층에서 0.1마일의 EDSU

Table 1. System parameters of scientific echosounder for acoustic survey during each season

\begin{tabular}{lccccc}
\hline \multirow{2}{*}{ Parameter } & Unit & \multicolumn{3}{c}{ Value } \\
\cline { 3 - 6 } & & Dec. 2006 & Apr. 2007 & Jun. 2007 & Oct. 2007 \\
\hline Transmit Frequency & $\mathrm{kHz}$ & 200 & 200 & 200 & 200 \\
Source Level & $\mathrm{dB} / / \mu \mathrm{Pa}$ & 221.5 & 221.5 & 221.5 & 221.5 \\
Receiver Sensitivity & $\mathrm{dBC} / / \mu \mathrm{Pa}$ & -51.7 & -51.7 & -51.7 & -51.7 \\
Beam Width & $\mathrm{degree}$ & 6.6 & 6.6 & 6.6 & 6.6 \\
Data Threshold & $\mathrm{dB}$ & -130 & -130 & -130 & -130 \\
Ping rate & $\mathrm{pps}$ & 5 & 3 & 5 & 5 \\
Pulse Width & $\mathrm{ms}$ & 0.1 & 0.3 & 0.5 & 0.3 \\
Absorption Coefficient & $\mathrm{dB} / \mathrm{m}$ & 0.0573 & 0.0573 & 0.0711 & 0.0769 \\
Sound Speed & $\mathrm{m} / \mathrm{s}$ & 1498.83 & 1498.83 & 1516.55 & 1524.74 \\
Collection Range & $\mathrm{m}$ & $1 \sim 90$ & $1 \sim 90$ & $1 \sim 90$ & $1 \sim 90$ \\
\hline
\end{tabular}

${ }^{1}$ The term "dBC//uPA" is short for "decibel counts per micropascal". Since BioSonics system digitizes the return echo envelope and uses a digital representation of voltage which called counts. Counts are proportional to volts (not a one to one ratio). 


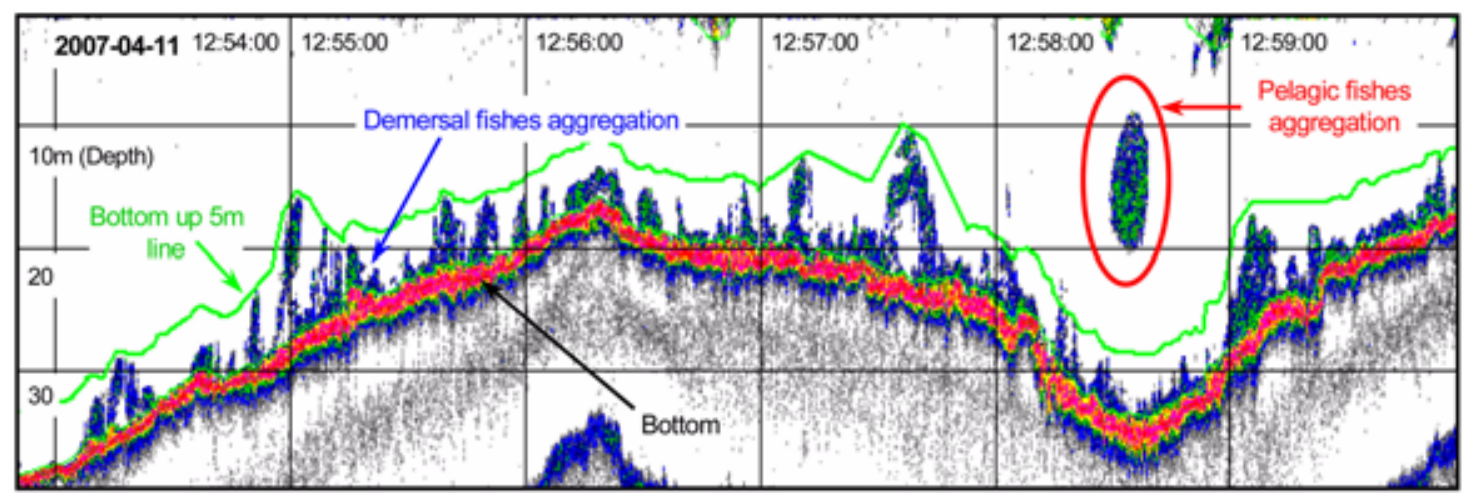

Fig. 2. Separation of acoustic layer for extracting fish aggregations around the bottom. The two layers were divided into (1) from surface to $5 \mathrm{~m}$ above bottom, and (2) up to $5 \mathrm{~m}$ above bottom (green line).

(Elementary Distance Sampling Unit) 간격으로 추출된 $\mathrm{NASC}$ 값을 어군의 시 · 공간 분포 특성에 이용하였다.

음향 빔 내에서 탐지되는 개개 어류의 음향 특성인 현 장 음향 표적강도 자료는 어류의 일반적인 음향 표적강도 함수(TS $=20 \cdot \log _{10}[$ fish length, $\mathrm{cm}]+b_{20}$ )로부터 탐지된 어류의 체장을 역으로 계산할 수 있다(McClatchie et al. 2003; Simmonds and MacLennan 2005). 조사 대상 해역 에서 음향 탐지된 어류는 대부분 경골 어류이며 체내에 부레를 가지고 있다. 이러한 어류의 음향 반사 특성은 수 산 음향 분야에서 많이 사용되는 $38 \mathrm{kHz}$ 에서는 많이 알려 져 있지만 상대적으로 고주파인 $200 \mathrm{kHz}$ 에서는 연구 결 과가 부족한 상황이다.

본 연구 지역에 존재하는 다양한 어류 체장을 가지고 있는 모든 종에 대해 $b_{20}$ 값을 측정하는 것은 현실적으로 불가능하다. 본 연구에서는 특정 어류에 대한 자원량 추정 이 아닌 저층 부근에 존재하는 어류의 총 자원량을 추정 하고자 하였기에 어종별 $b_{20}$ 값을 사용하기 보다는 경골 어류의 일반적인 $b_{20}$ 값을 사용하였다. 이러한 근거는 연 안 저층 부근에 존재하는 많은 어류가 경골 어류이며, $b_{20}$ 값을 이끌어내기 위한 실험은 다양한 체장을 가진 어류를 대상으로 하기 때문이다.

일반적으로 부레를 가진 경골 어류의 $38 \mathrm{kHz}$ 에 대한 $\mathrm{TS}$ 함수에서 $b_{20}$ 값은 $-67 \sim-68 \mathrm{~dB}$ 의 범위를 갖고 있다. 이러한 $b_{20}$ 값은 동일한 부레를 갖는 경골 어류에서 주파 수가 증가하면 감소하는 것으로 알려져 있으며 $200 \mathrm{kHz}$ 의 경우 $b_{20}$ 값은 $38 \mathrm{kHz}$ 보다 약 $4 \sim 5 \mathrm{~dB}$ 정도 낮은 $-72 \sim-73 \mathrm{~dB}$ 로 측정되었다(강 2002). 따라서 본 연구의 $200 \mathrm{kHz}$ 음향 자료에서 수신된 현장 TS 자료로부터 어류 의 체장을 역으로 추정하기 위한 $b_{20}$ 값은 $-72 \mathrm{~dB}$ 로 하였 다(Kang and Hwang 2003).

\section{저층 부근 어류의 현존량 계산}

음향 조사를 통한 저층 부근의 자원량 계산을 위해
동-서 방향의 정선에서의 취득한 0.1 마일 간격의 NASC 값을 사용하였다. NASC 값은 체적내의 어류로부터 수 신되는 신호의 선형적인 합이므로 어군의 밀도는 취득한 해수 체적 내의 평균 NASC 값을 어류의 TS 값으로 나 눔으로써 계산할 수 있으며(Hewitt and Demer 1993; SonarData 2000), 이때 $b_{20}$ 값은 $-72 \mathrm{~dB}$ 로 하였다. 따라 서, 체장 $(L, \mathrm{~cm})$ 에 따른 어류 $\mathrm{TS}$ 및 후방산란 단면적 $\left(\sigma=4 \pi 10^{T S / 10}\right)$ 은 다음과 같이 표현된다.

$$
\begin{aligned}
& T S=20 \cdot \log _{10}(L)-72 \\
& \sigma=4 \pi 10^{-7.2} \cdot L^{2.0}
\end{aligned}
$$

한편, 조사 지역에서 삼중자망과 통발을 이용한 우점 어류는 시기별로 차이를 보이나 2007년 10월 어류 채집 조사 결과 놀래기류, 쥐치류, 볼락류가 우점하고 있었다 (해양수산부 2007). 음향 자료로부터 저층 부근에 분포하 는 개개 어류의 자원량 추정이 아닌 저층 어류 전체의 현 존량을 추정하기 위함이므로 저층 부근에 분포하는 우점 어류 전체를 이용하였으며 이때 체장 $(L, \mathrm{~cm})-$ 체중 $(w, \mathrm{~g})$ 관계 $\left(w=a L^{b}\right)$ 는 다음의 관계식으로 나타났다.

$$
w=0.00987 \cdot L^{3.189}
$$

그러므로 어류의 밀도 $(\rho)$ 의 추정은 식 (1)과 (2)에 의해 다 음 식으로 구할 수 있다.

$$
\rho=(N A S C / \sigma) \cdot w=3.63 \times 10^{-3} \cdot L^{1.189} \cdot N A S C
$$

식 (4)에서 표현된 모든 항들은 단일 어군에 관한 식을 길이의 함수로 표현하였으므로 위 식을 주요 어군의 일반 적인 길이 분포에 관한 식으로 바꾸어 주어야 한다. $\mathrm{NASC}$ 는 모든 길이의 어류에 의한 영향이므로 어류의 표 준 길이 분포를 식 (4)에 적용해야 한다. 이를 위하여 연구 지역에서 채집한 주요 어군의 표준 길이당 상대적 빈도수 (relative frequency) 결과를 이용하였다. 그러므로 연구 지 
역에서 관측된 0.1 마일 간격의 NASC 자료로부터 주요 어 군의 길이 분포를 고려하여 계산되는 최종 어류의 밀도 $(\rho)$ 는 아래와 같이 나타낼 수 있다.

$$
\rho=3.63 \times 10^{-3} \cdot \sum_{i=1}^{n} f_{i} L i^{1.189} \cdot N A S C
$$

여기서, $f_{i}$ 는 표준 체장 $L_{i}$ 에 대한 어류의 상대 빈도이다.

식 (5)의 우변 항에서 $\mathrm{NASC}$ 를 제외한 나머지 부분은 어류의 TS 특성과 체장-체중을 고려한 부분으로 음향 추 정치를 어류의 분포 밀도로 변환하는 변환 계수(conversion factor, $\mathrm{CF}$ )이며, 본 연구에서 계산된 $\mathrm{CF}$ 는 0.142 였다.

수신된 음향 자료와 변환 계수로부터 계산된 밀도 자료 를 이용하여 각 정선별 평균 밀도를 계산하였으며, 전체 조사 해역의 평균 어군 밀도 $(\bar{\rho})$ 는 정선별 평균 밀도 자 료의 가중 평균(weighted mean) 계산은 식 (6)으로부터 계산하였다.

$$
\bar{\rho}=\frac{\sum_{i=1}^{N} \bar{\rho}_{i} \cdot n_{i}}{\sum_{i=1}^{N} n_{i}}
$$

여기서, $\bar{\rho}_{i}$ 는 $i$ 번째 정선의 평균 밀도, $n_{i}$ 는 $i$ 번째 정선에 서 $\mathrm{EDSU}$ 수, $N$ 은 정선 수를 나타낸다. 이상의 관계식에 서 조사 해역 저층 부근의 어류 현존량(standing stock, $B$ ) 은 전체 조사 해역의 평균 어군 밀도 $(\bar{\rho})$ 와 조사 해역의 면적의 곱 $\left(A, \mathrm{~m}^{2}\right)$ 으로 계산하였다(Jolly and Hampton 1990).

$$
B=A \times(\bar{\rho})
$$

한편, 각 정선의 평균 밀도와 전체 조사 지역의 평균 밀 도로부터 전체 조사 지역에서 평균 밀도의 변동(variance, $v a r$ )과 현존량의 변동 계수(coefficient of variance, $\mathrm{CV}$, $\%$ )는 아래의 관계식으로부터 계산하였다. $C V$ 값이 작을 수록 정선간 밀도 편차가 작아 어류 분포가 고르게 나타 남을 의미한다.

$$
\begin{aligned}
& \operatorname{var}(\bar{\rho})=\frac{N}{N-1} \frac{\sum_{i=1}^{N}\left(\bar{\rho}_{i}-\bar{\rho}\right)^{2} \cdot n_{i}^{2}}{\left(\sum_{i=1}^{N} n_{i}\right)^{2}} \\
& \operatorname{var}(B)=A^{2} \times \operatorname{var}(\bar{\rho}) \\
& C V=\frac{\sqrt{\operatorname{var}(B)}}{B}
\end{aligned}
$$

음향 자료와 어획 자료로부터 저층 어류의 현존량을 계

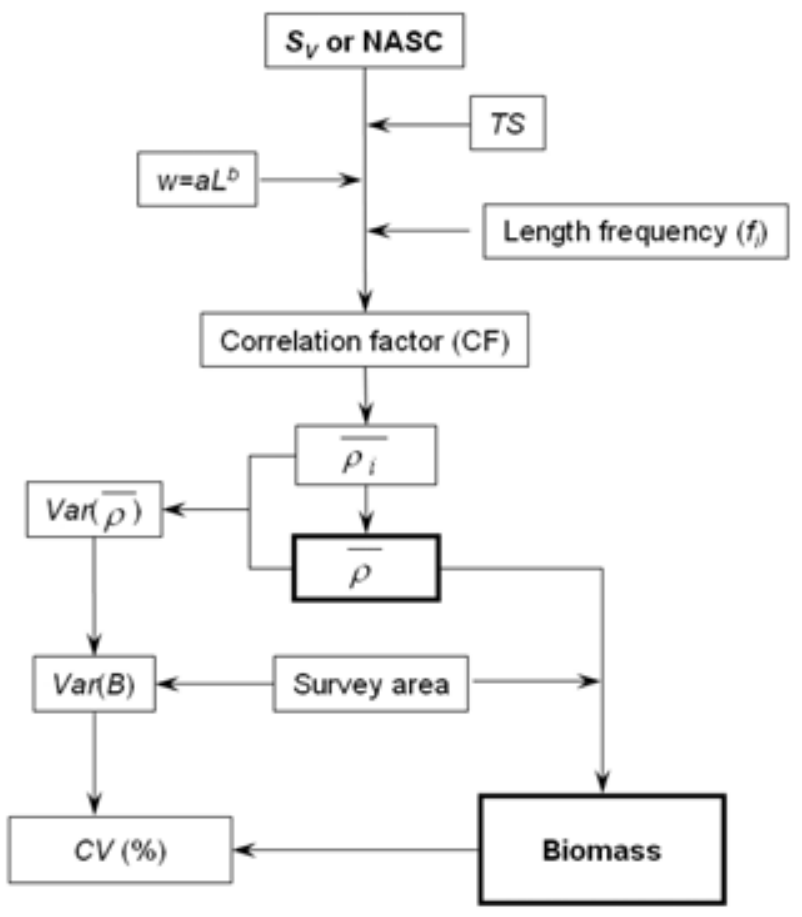

Fig. 3. Flow chart on the data processing for standing stock calculation of demersal fish using acoustic and fish catches data.

산하는 자료 처리 흐름을 각각의 단계로 분리하여 요약하 였다(Fig. 3)

\section{3. 결 과}

제주 서쪽 연안 지역에서 4 계절에 걸쳐 실시한 음향 조 사 자료를 이용하여 해저면과 해저면 위 $5 \mathrm{~m}$ 사이의 저층 부근의 수 층에 분포하는 어군의 계절 및 공간 분포 특성 을 파악하였으며, 우점 어류의 음향 특성을 이용하여 저층 부근 어류의 현존량을 추정하였다.

\section{저층 부근 어류의 수직 분포}

제주도 서쪽 연안에서 4계절에 걸쳐 실시한 음향 조사 에서 저층 부근 어류의 대부분은 수심 20 30 m 부근의 사면에 주로 분포하는 특성을 보이고 있었으며, 특히 수심 20 30 m를 가지는 경사면 지역의 해저면 해저면 위 $5 \mathrm{~m}$ 사이 수 층에 집중적으로 분포하는 형태를 보여 수심 종 속성이 강하게 나타나고 있다(Fig. 4). 한편, 전체적으로 어군의 분포가 미약하게 나타나는 동계 시기에는 저층 어 군 또한 분포 강도가 약하게 존재하고 있지만, 하계 및 추 계 기간에는 저층 부근의 분포 강도가 크게 나타나 계절 에 따른 저층 부근의 어류 분포 특성의 변화를 보여주고 있다. 

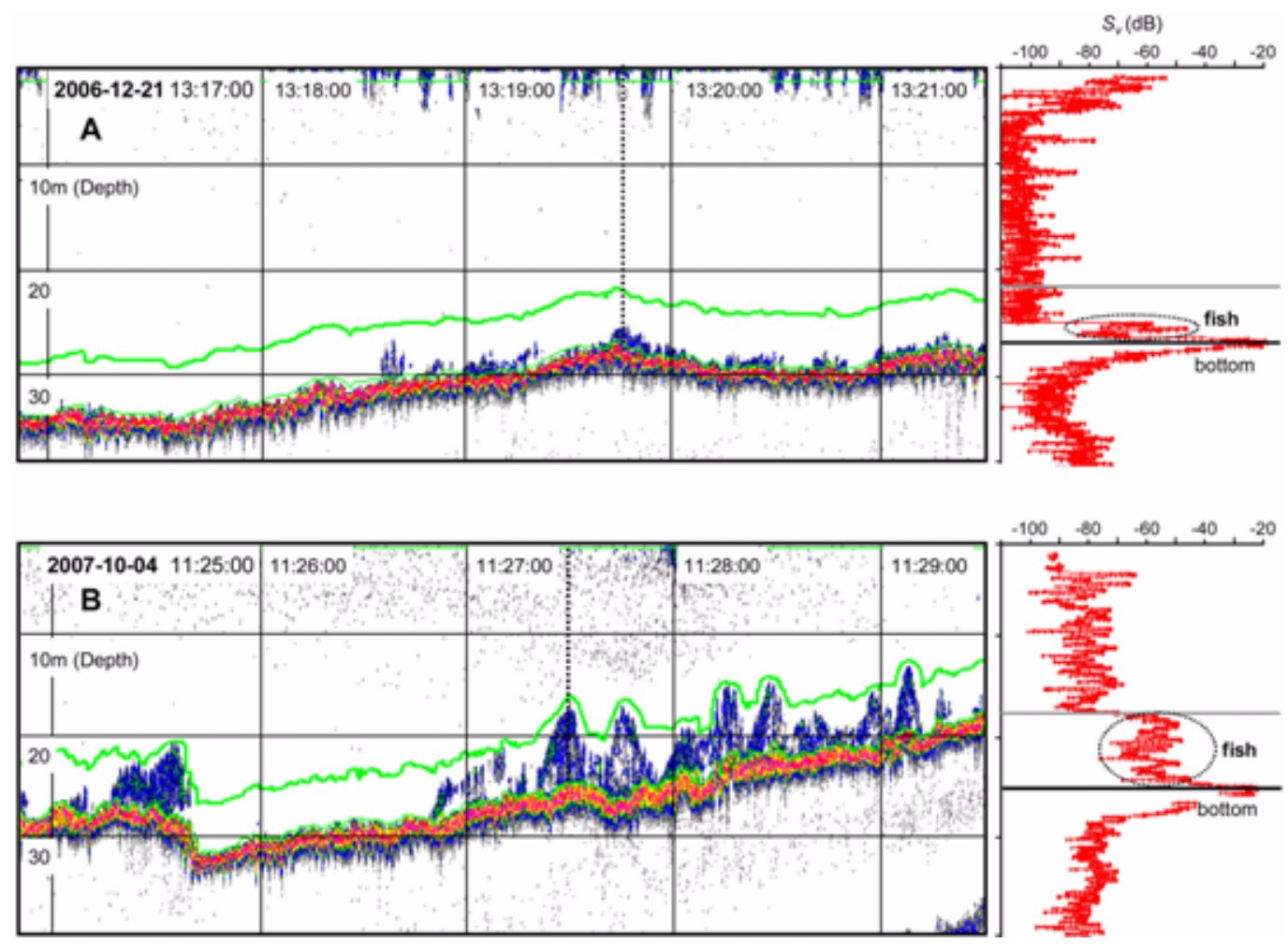

Fig. 4. Example on the representative vertical echogram of demersal fish aggregations with season (A: December 2006, B: October 2007). Almost fish aggregations are detected at bottom slope between 20 and $30 \mathrm{~m}$ depth.

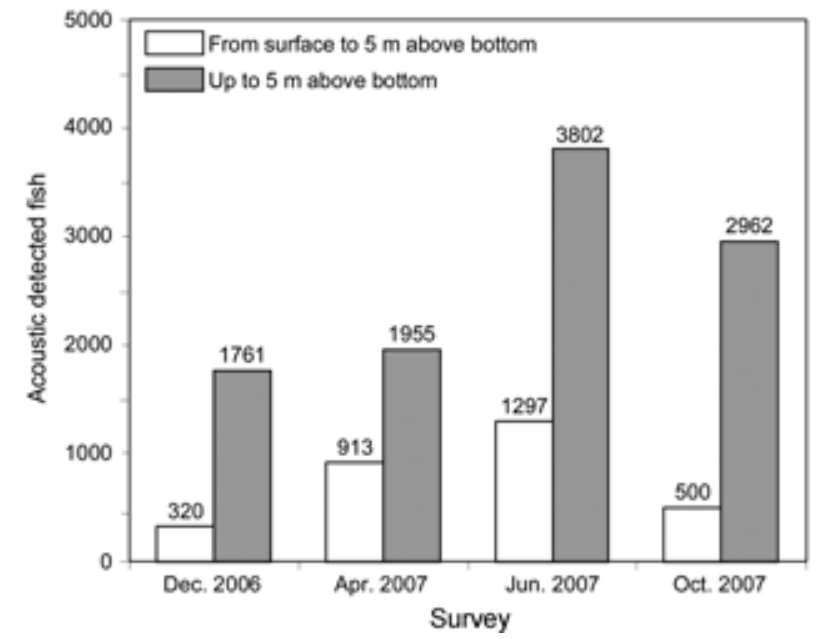

Fig. 5. A number of acoustic detected individual fish with season at two water layers (from surface to $5 \mathrm{~m}$ above bottom, up to $5 \mathrm{~m}$ above bottom). The all data are derived from in situ TS data along acoustic transect.

이러한 저층 부근에 존재하는 어군의 계절 분포 특성은 조사 지역 전체에서 탐지된 개개 어류의 현장 음향 표적 강도 자료에서도 나타나고 있다(Fig. 5). 즉, 동계와 춘계
시기보다는 하계 및 추계 시기에 탐지된 어류 개체수가 증가하고 있으며, 특히 하계의 경우 동계 및 춘계 시기보 다 약 2 배에 가까운 많은 어군 분포가 탐지되었다. 표층 해저면 위 $5 \mathrm{~m}$ 수 층에서 탐지된 개개 어류의 개체수는 해저면 해저면 위 $5 \mathrm{~m}$ 수 층에서 탐지된 어류에 비해 모 든 계절에서 작게 나타나고 있었다. 그러나 저층 부근의 분포와는 달리 춘계와 하계 시기에 많은 개체수가 탐지되 어 계절적 회유어의 영향임을 보여주고 있다.

탐지된 개개 어류의 TS 자료 가운데 해저면 해저면 위 $5 \mathrm{~m}$ 사이 수 층에 분포하는 자료로부터 추정한 개개 어류 의 길이 분포에서는 체장 $15 \sim 25 \mathrm{~cm}$ 의 중간 길이를 가진 어류 분포 비율은 계절별로 큰 차이를 보이지 않았다. 그 러나 체장 $15 \mathrm{~cm}$ 미만의 어류는 추계 동계 시기에 분포 비율이 크게 나타났으나, $30 \mathrm{~cm}$ 이상의 길이를 가진 어류 는 춘계와 하계 시기에 분포 비율이 상대적으로 높아 계 절별로 체장 분포 특성이 다르게 나타남을 보여주고 있다 (Fig. 6).

\section{저층 부근 어류의 공간 분포}

동일한 조사 지역에서 실시한 해저면 부근 어류의 공간 분포는 계절별로 큰 차이를 가지고 있는 것으로 조사되었 다. 저층 어군이 가장 많이 분포하는 지역은 하계로 접어 

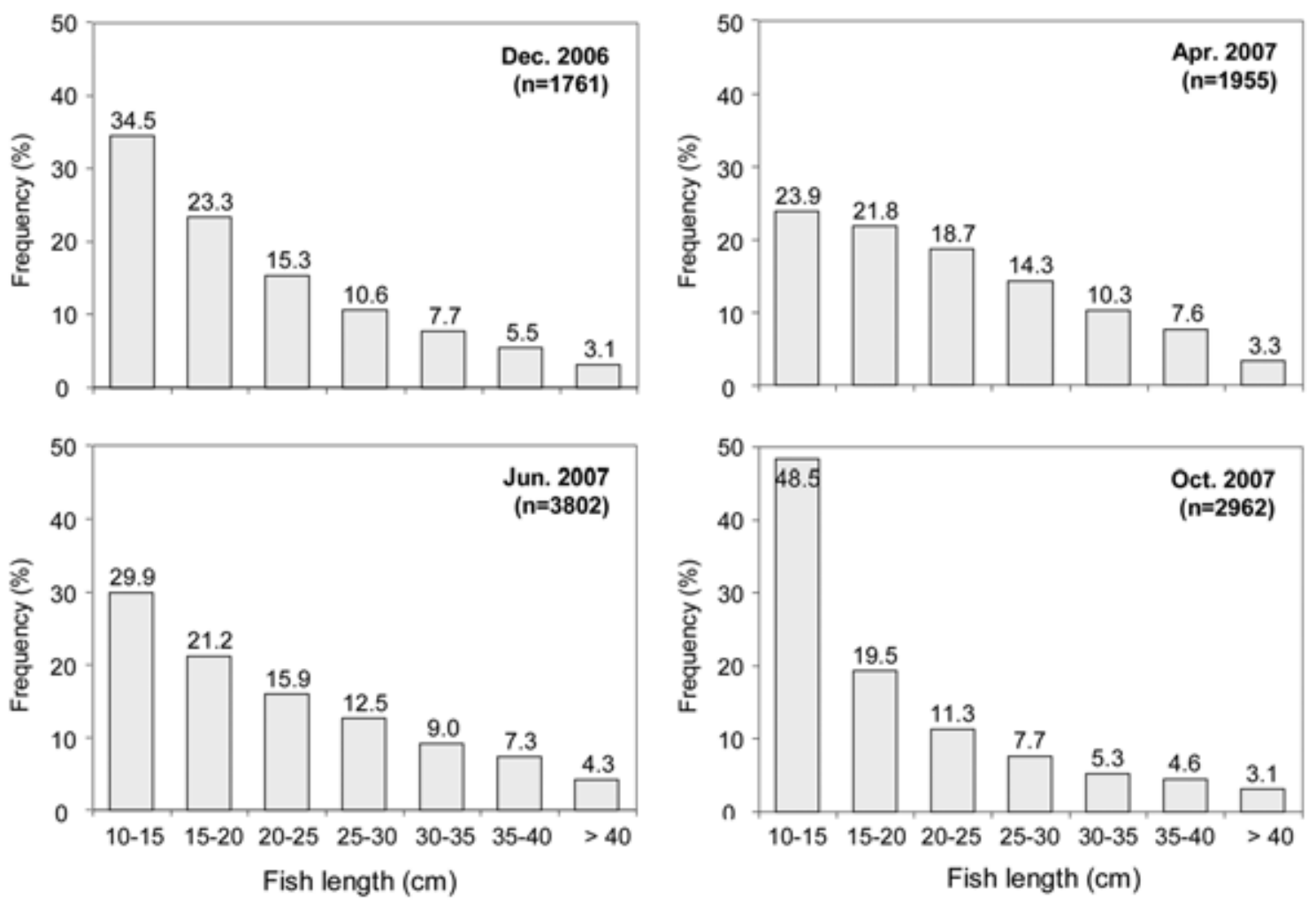

Fig. 6. Length frequency of fish up to $5 \mathrm{~m}$ above bottom with seasons. The data are derived from in situ TS data along acoustic transect.

드는 6월에 조사 지역의 북쪽에 위치한 신창리 서쪽의 수 심 20 30 m 해역이었다(Fig. 7). 이 해역은 동계 시기를 제외한 전 계절에서도 조사 해역 가운데 가장 높은 저층 어군 분포를 나타내었다. 순간 최대 어군 밀도 $(\rho)$ 는 6 월에 관측된 0.1 마일 간격의 $\mathrm{NASC}$ 값에서 최대치는 1,616 으 로 식 (5)의 변환 계수와 $1 \mathrm{EDSU}$ 를 고려했을 때 약 $22.7 \mathrm{~g} / \mathrm{m}^{2}$ 로 추정되었다.

신창리 이외에 어군 밀도가 높은 지역은 차귀도, 와도, 죽도에 근접한 섬의 남쪽 주변에서 상대적으로 높은 분포 를 보이고 있었으며, 그 외 나머지 지역에서는 전 계절에 걸쳐 해저면 부근에서의 어군 분포는 약한 것으로 탐지되 었다. 전체적으로 조사 지역에서 저층 부근의 어류는 수심 20 30 m 부근의 사면이 존재하는 공간에 주로 분포하는 것으로 나타나고 있었다.

\section{저충 부근 어류의 현존량}

어류의 $\mathrm{TS}$ 함수, 체장-길이 함수, 어류 길이 분포를 이 용한 변환 계수와 음향 조사를 통해 관측한 NASC 값으 로부터 해저면 해저면 위 $5 \mathrm{~m}$ 수 층에 대해 계절별로 어 류 밀도를 계산한 후 조사 면적 $\left(2.29 \times 10^{7} \mathrm{~m}^{2}\right)$ 을 이용하여 저층 부근 어류의 현존량을 추정하였다(Table 2).

평균 어군 밀도 $(\bar{\rho})$ 는 하계 기간에 $1.35 \mathrm{~g} / \mathrm{m}^{2}$ 으로 가장
높았으며, 동계 기간은 $0.14 \mathrm{~g} / \mathrm{m}^{2}$ 으로 가장 낮은 값을 보 였다. 이러한 평균 밀도로부터 계절별 저층 어류의 현존량 은 동계 기간 3.2 톤 $(\mathrm{CV} 21.8 \%)$, 춘계 기간 17.9 톤 $(\mathrm{CV}$ $21.6 \%)$, 하계 기간 30.8 톤 $(\mathrm{CV} 17.8 \%)$, 추계 기간에는 22.5 톤 $(\mathrm{CV} 24.2 \%)$ 으로 추정되어 하계 기간에 가장 많은 어군이 존재함을 보여주고 있다.

\section{4. 고 찰}

연구 대상 해역인 신창리-수월봉을 잇는 지역은 제주 연안 해역의 일반적인 특성처럼 계절에 따른 해류 흐름에 의해 어류의 이동이 활발하여 다양한 수산 생물이 서식하 여 자원 생물학적 가치가 높은 해역으로 알려져 왔다(방 과 김 1993; 차 등 2001). 따라서 많은 조사들이 중층 어 류 등에 초점을 맞추어 이루어져 있으나 제주도 형성 기 작에 의해 연안 암반이 발달한 제주도에서 중요한 수산 자원인 해저면 부근의 어류에 대한 분포 특성 연구는 상 대적으로 부족한 상황이었다.

중층 어류에 의한 연구는 자망을 이용하는 일반적인 방 법으로 접근이 용이하나 해저면 근처에 분포하는 어류의 조사는 통발을 이용하므로 상대적으로 조사 면적의 제한 성이 큰 한계점이 있어 자원량 추정 및 분포 위치 파악에 


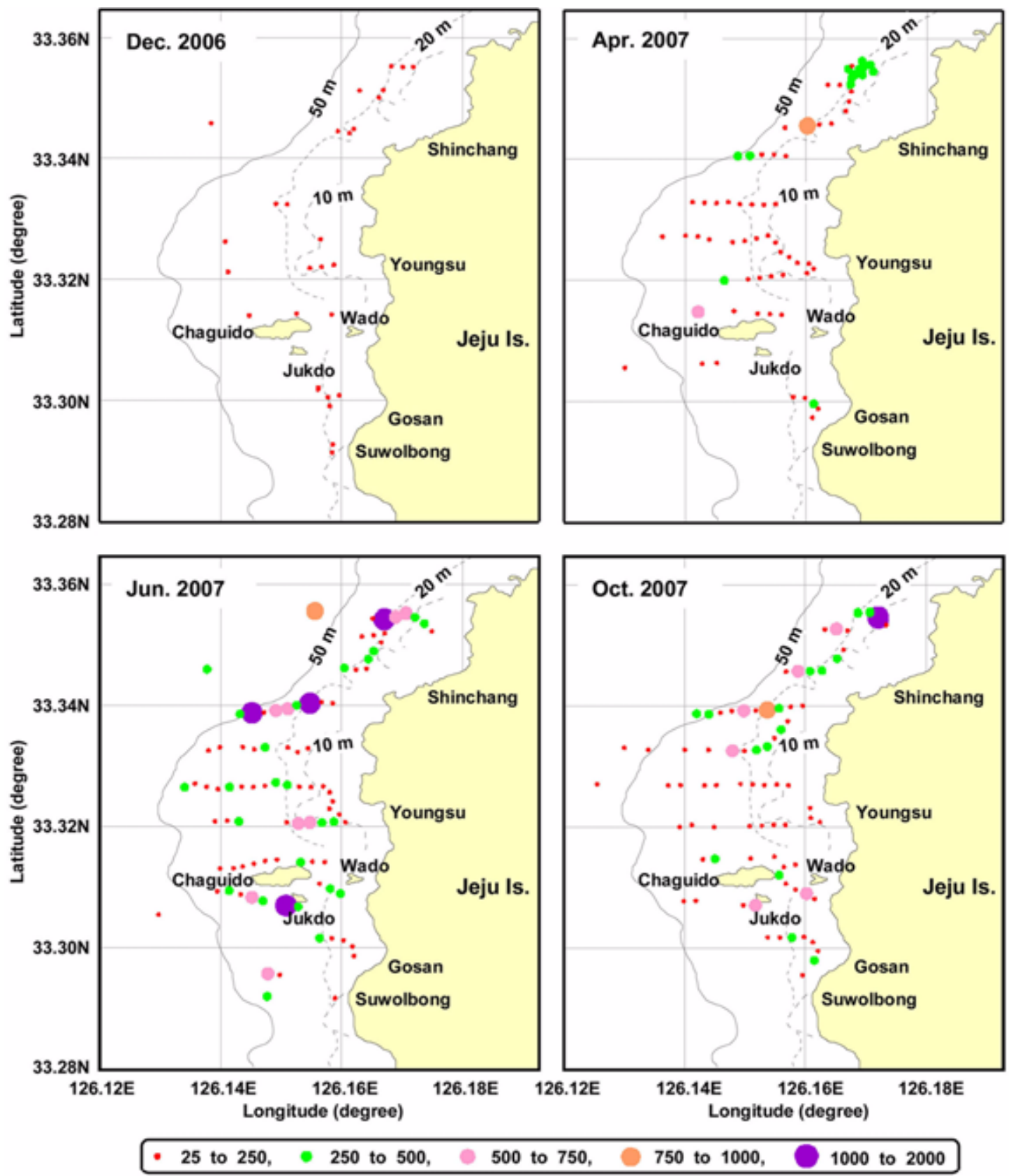

Fig. 7. Spatio-temporal distribution of fish aggregations around bottom using nautical area scattering coefficient (NASC, $\mathrm{m}^{2} / \mathrm{mile}^{2}$ ) data with 0.1 mile interval.

현실적인 어려움이 존재하고 있다. 본 연구에서는 이러한 어려움을 극복하기 위한 방법으로 수심 분해능이 큰 고주 파 음향 센서를 이용하여 해저면 부근에서 서식하는 어류 의 음향 조사를 실시하였다. 이러한 저층 어류의 음향 조 사는 중층 어류 조사보다는 상대적으로 작지만 최근에 다 양하게 시도하고 있으며 그 효용성이 규명되고 있다 (Benoit-Bird et al. 2003; Doray et al. 2006).

4계절에 걸친 음향 조사를 통한 저층 어군에 대한 시· 공간 분포 파악은 저층 부근에 분포하는 어류에 의해 반
사된 음향 적분치를 이용하였으므로 조사 지역의 분포 특 성을 전체적으로 보여주고 있다. 이러한 분포 특성은 수심 5 90 m까지 모든 수심에 대해 특정 지역이 아닌 전 조사 지역에 대해 실시한 결과이므로 자망이나 통발에 의한 시·공간 조사 결과보다는 자료의 편차가 작을 것이다. 따 라서, 연안 지역의 해저면에 분포하는 어류 자원의 수직 및 공간 구조 파악을 위한 음향 조사 기법은 조사 정선이 충분히 확보된다면 이전의 연구 결과에서 보여주는 어군 파악 결과에 또 다른 결과를 제공할 것이다. 
Table 2. Standing stock estimation of fish aggregations around bottom using acoustic survey in western coast of Jeju island, Korea. The $n_{i}$ is the number of 0.1 EDSU and the NASC is mean value of the nautical area scattering coefficient $\left(\mathrm{m}^{2} / \mathrm{mile}^{2}\right)$ along $i$-th transect

\begin{tabular}{|c|c|c|c|c|c|c|c|c|}
\hline \multirow{2}{*}{ Transect \# } & \multicolumn{2}{|c|}{ Dec. 2006} & \multicolumn{2}{|c|}{ Apr. 2007} & \multicolumn{2}{|c|}{ Jun. 2007} & \multicolumn{2}{|c|}{ Oct. 2007} \\
\hline & $n_{i}$ & NASC & $n_{i}$ & NASC & $n_{i}$ & NASC & $n_{i}$ & NASC \\
\hline 1 & 15 & 14.9 & 19 & 131.0 & 14 & 231.6 & 14 & 64.4 \\
\hline 2 & 13 & 5.4 & 13 & 45.9 & 14 & 45.5 & 15 & 66.5 \\
\hline 3 & 13 & 13.8 & 14 & 82.7 & 15 & 54.4 & 12 & 96.8 \\
\hline 4 & 4 & 0.8 & 14 & 86.4 & 17 & 164.1 & 17 & 209.8 \\
\hline 5 & 10 & 15.0 & 17 & 58.6 & 18 & 59.6 & 14 & 99.7 \\
\hline 6 & 15 & 13.2 & 14 & 56.7 & 18 & 111.4 & 21 & 44.8 \\
\hline 7 & 14 & 25.1 & 19 & 61.1 & 16 & 147.0 & 17 & 55.2 \\
\hline 8 & 16 & 12.8 & 14 & 71.1 & 14 & 77.3 & 17 & 30.6 \\
\hline 9 & 16 & 4.5 & 18 & 11.3 & 17 & 87.1 & 14 & 51.7 \\
\hline 10 & 15 & 8.1 & 15 & 43.0 & 17 & 39.0 & 13 & 36.9 \\
\hline 11 & 16 & 0.9 & 16 & 0.5 & 12 & 55.7 & 10 & 21.9 \\
\hline 12 & 13 & 0.2 & 14 & 0.4 & 11 & 38.7 & 8 & 1.0 \\
\hline$\sum_{i=1} n_{i}$ & \multicolumn{2}{|r|}{160} & \multicolumn{2}{|c|}{187} & \multicolumn{2}{|c|}{182} & \multicolumn{2}{|c|}{172} \\
\hline Conversion Factor $(\mathrm{CF})$ & \multicolumn{2}{|r|}{0.142} & \multicolumn{2}{|c|}{0.142} & \multicolumn{2}{|c|}{0.142} & \multicolumn{2}{|c|}{0.142} \\
\hline Mean density $\left(\bar{\rho}, \mathrm{g} / \mathrm{m}^{2}\right)$ & \multicolumn{2}{|r|}{0.14} & \multicolumn{2}{|c|}{0.78} & \multicolumn{2}{|c|}{1.35} & \multicolumn{2}{|c|}{0.98} \\
\hline Survey area $\left(A, \mathrm{~m}^{2}\right)$ & \multicolumn{2}{|r|}{$2.29 \times 10^{7}$} & \multicolumn{2}{|c|}{$2.29 \times 10^{7}$} & \multicolumn{2}{|c|}{$2.29 \times 10^{7}$} & \multicolumn{2}{|c|}{$2.29 \times 10^{7}$} \\
\hline Estimated Biomass $(B$, to & \multicolumn{2}{|r|}{3.2} & \multicolumn{2}{|c|}{17.9} & \multicolumn{2}{|c|}{30.8} & \multicolumn{2}{|c|}{22.5} \\
\hline Coefficient of variation & $\%)$ & $21.8 \%$ & \multicolumn{2}{|c|}{$21.6 \%$} & \multicolumn{2}{|c|}{$17.8 \%$} & \multicolumn{2}{|c|}{$24.2 \%$} \\
\hline
\end{tabular}

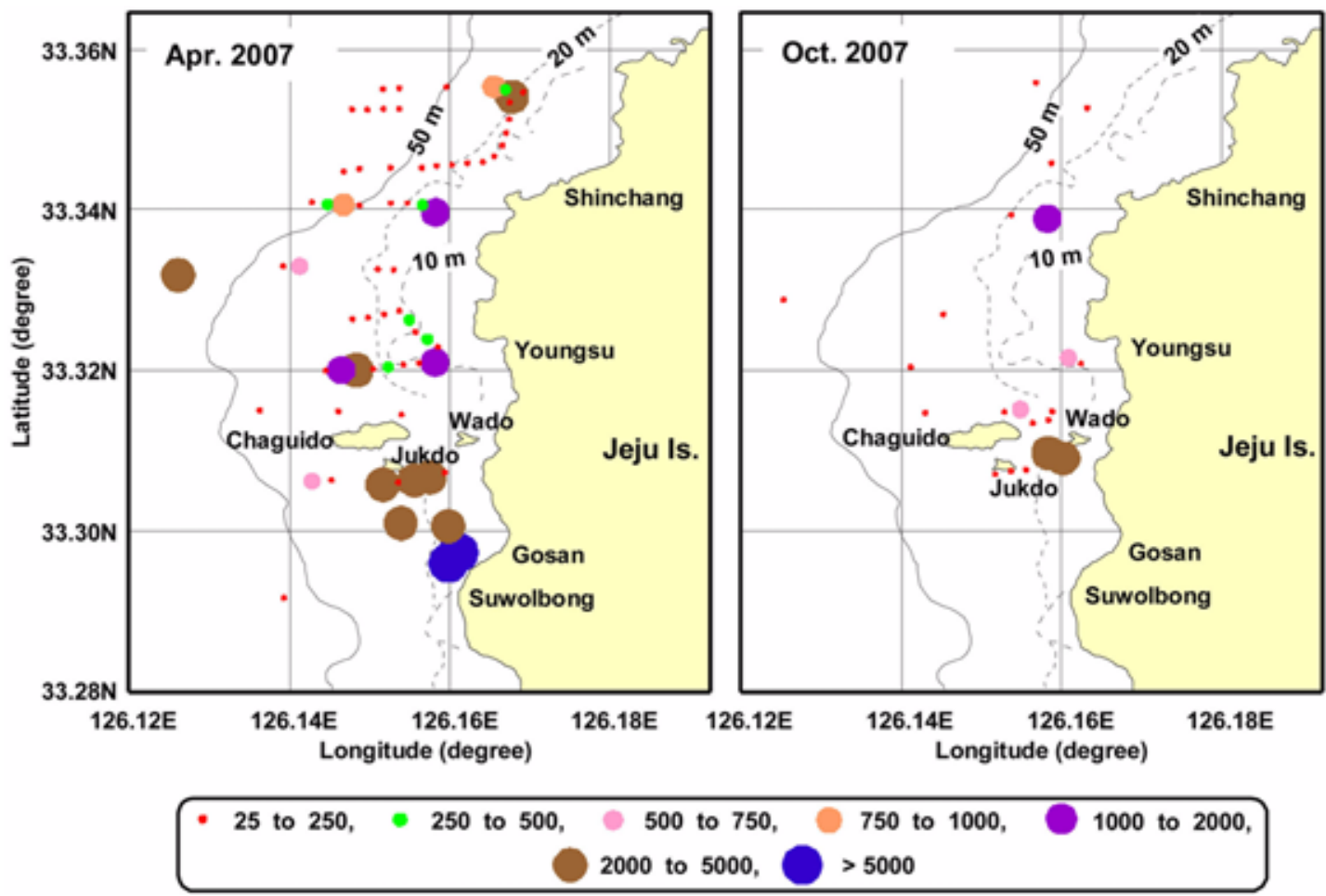

Fig. 8. Spatial distribution of pelagic fish aggregations on April and October 2007 using nautical area scattering coefficient (NASC, $\mathrm{m}^{2} / \mathrm{mile}^{2}$ ) data with 0.1 mile interval. 
연안 음향 자원 조사의 장점 가운데 하나는 조사선이 이동하는 모든 정선에 대해 수 층 전체의 정보를 동시에 얻을 수 있는 것이다. 본 연구에서는 주로 해저면 근처의 음향 자료만을 이용하였으나 사용하지 않은 해수면 해저 면 위 $5 \mathrm{~m}$ 수 층 사이의 정보를 이용하여 중층에 존재하 는 어류의 시· 공간 분포를 분석, 고찰하였다.

중층 어류는 계절적인 영향을 받는 부어류나 회유어일 가능성이 크므로 이들이 주로 분포하는 춘계와 추계 시기 의 분포 경향은 저층 어류와는 다른 경향을 보이고 있었 다(Fig. 8). 춘계 시기에는 죽도 남쪽과 수월봉 사이에서 대규모 어군이 존재하였고, 그 외에 용수와 고산 등 조사 지역 전체에서 강한 어군을 형성하는 것으로 나타났으며, 이러한 어군은 부어류일 가능성이 큰 것으로 추정된다. 추 계 시기의 공간 분포 강도는 춘계 시기에 비해 낮게 나타 나 조사 지역에서 부어류나 회유어는 춘계 시기에 크게 분포함을 알 수 있었다. 이러한 중층 어류의 분포는 저층 어류의 시·공간 분포와는 전혀 다른 분포 특성을 보여 동 일한 해역이고 연안 지역임에도 불구하고 저층 부근과 중 층에서의 분포 형태가 다를 수 있음을 직접적으로 보여주 고 있다.

춘계 시기에 음향 탐지된 현장 TS 자료를 통한 개개 어 류의 개체수와 NASC 분포가 서로 일치하지 않고 있다. 즉, 저층 부근의 어류 탐지 개체수(1,955개체)가 중층의 개체수(913개체)보다 더 크게 나타나고 있으나 NASC 분 포에서는 중층의 분포 강도가 더 크게 나타나고 있다. 이 러한 불일치는 분포 어류의 군집 특성과 음향 시스템의 수직 분해능에 직접적인 원인이 있다. 저층 어류의 경우 군집 형성 보다는 개개 어류가 분포하는 형태를 가지나 중층의 부어류는 어군을 이루어 개개 어군을 분리해내는 음향 분해능 내에 복수의 개체가 존재할 가능성이 클 수 있다. 따라서 음향 조사에서 중층에 탐지된 개개 어류의 개체 수는 실제보다 작을 수 있다. 저층 어류의 경우 암반 구멍 속에 서식하는 어류들과 같이 음향 신호를 이용하여 해저면과 분리하기가 거의 불가능한 경우가 존재하므로 음향 탐지된 저층 개개 어류의 개체 수는 중층과 같이 실 제보다 작을 수 있다.

저층 어류의 시·공간 분포 특성 파악 이외에 부가적으 로 음향 자료로부터 저층 부근에 서식하는 어류의 현존량 을 추정하였다. 시기별로 차이를 보이지만 현존량은 하계 에 30.8 톤으로 동계의 3.2 톤에 비해 약 10 배에 정도의 차 이를 보이는 것으로 나타났다. 이러한 현존량 추정은 수신 된 NASC 값, $200 \mathrm{kHz}$ 에 대한 경골 어류의 일반적인 TS 함수, 추계 시기에 채집된 체장-체중 함수로부터 계산되었 다. 이러한 저층 부근의 계절별 현존량 추정은 기존의 어 류 조사가 종 조성, 군집 분석, 다양도 등 대부분의 연구 결과가 정성 분석에 치우친 자료이므로 정량적 측면에서
현존량 추정은 큰 의미가 있다.

현존량 추정을 위한 자료 처리 과정에서 사용한 NASC 값은 현장에서 관측한 값으로 조사 당시의 어류 분포 특 성 정보를 가지고 있으므로 변하지 않는 관측 값이다. 그 러나 TS 함수는 경골 어류에 해당하는 일반적인 TS 함수 를, 체장-체중 함수는 4 계절 가운데 추계 시기의 자료만을 사용하였다. 따라서, 음향 자료를 통한 좀 더 정확한 저층 부근의 어류 자원량 파악을 위해서는 조사 지역에서 우점 하는 어류에 대한 TS 자료와 음향 조사와 동일한 시기에 체장-체중 함수에 대한 조사가 추가되어야 할 것이다 (Everson et al. 1996; Reid et al. 2000; Diachok et al. 2001).

본 연구에서는 제주도 서쪽 연안 지역에서 4 계절에 걸 친 음향 조사를 통하여 저층 부근에 서식하는 어류의 시· 공간 분포 특성을 파악하였다. 기존의 어구 어법을 이용한 시· 공간 분포 조사에서 가지는 어려움을 극복하기 위한 음향 조사 기법의 적용은 저층 어류 뿐만 아니라 중층 어 류에 대한 시·공간 분포 결과를 직접적으로 보여줄 수 있 으며, 또한 우점 어류의 정보가 주어진다면 현존량 추정까 지 가능함을 보여주고 있다. 이러한 접근 방법은 우리나라 연안 어류에 대한 연구가 주로 정성 분석 측면을 많이 고 려한 현 시점에서 정량 분석 측면에서 또 다른 접근법을 제공할 것이다.

\section{5. 결 론}

본 연구에서는 제주도 서쪽 연안에서 4계절에 걸친 음 향 조사를 통하여 해저면 부근에 서식하는 어류의 시·공 간 분포 특성을 파악하였다. 음향 조사를 위한 센서는 $200 \mathrm{kHz}$ 분할빔으로 소형 예인체에 설치한 후 조사선의 선측에서 예인하였다. 음향 조사를 위한 정선 수는 12 개 였으며 총 조사 거리는 23 24마일이었다.

음향 조사 결과, 해저면 부근의 저층 어류는 수심 20 $30 \mathrm{~m}$ 의 사면 부근에 집중적으로 분포하고 있으며 탐지 개 체수 및 분포 강도는 하계 시기에 가장 컸다. 저층 어류의 공간 분포는 신창리 서쪽 연안에서 가장 밀도가 높게 나 타났으며, 섬 주변에서도 상대적으로 높은 분포를 보였 다. 중층 부어류는 춘계 시기에 가장 높았으며 차귀도 남 쪽에서 가장 강한 분포를 가지고 있었다. 음향 적분치, 어 류의 TS 함수, 체장-체중 함수로부터 계산한 저층 부근 어 류의 현존량은 하계 기간에 30.8 톤으로 가장 높았으며, 추 계 22.5톤, 춘계 17.9톤, 동계 3.2톤 순서로 추정되었다.

본 연구에서 실시한 연안 해역에서의 계절별 음향 자원 조사는 정성 분석에 치우친 현재까지의 연안 어류 자원 연구에 시·공간 분포 특성 파악에 필요한 기초 자료를 제 공할 것으로 판단된다. 


\section{사 사}

본 연구는 한국해양연구원과 국립수산과학원 제주수산 연구소가 수행하고 있는 해양수산부의 “동·서-제주해역 바다목장화 개발 연구용역(BSPM42400-1897-3)”와 “자 원조사 및 평가(RP-2008-FR-013)"의 지원을 받아 수행되 었습니다.

\section{참고문헌}

강돈혁. 2002. 참돔과 조피볼락의 음향 산란 특성. 이학박사 학위논문, 한양대학교. 196 p.

고유봉, 신희섭. 1990. 제주도 남부 화순연안 수산자원 유영 생물의 종조성과 다양도. 한국어류학회지, 2(1), 36-46.

김인옥, 노홍길. 1994. 제주도 주변해역에 출현하는 중국대륙 연안수에 관한 연구. 한국수산학회지, 27(5), 515-528.

김준택, 정동근, 노홍길. 1999. 제주도 한림 연안 정치망 어장 의 환경 특성과 어획량 변동에 관한 연구 III. 어획량 변 동과 환경요인. 한국수산학회지, 32(1), 105-111.

명정구, 조선형, 박정호, 백상규, 김종만, 강필선. 2003. 다이 빙 조사에 의한 가을철 가거도 연안의 어류상. 한국어류 학회지, 15(3), 207-211.

방익찬, 김태희. 1993. 제주도 서부 연안역의 용승. 제주대학 교 해양연구소 논문집, 17, 1-12.

이승종, 고유봉, 김병직. 2006. 제주도 서부 해역의 난자치어 분포와 종조성의 계절변동. 한국어류학회지, 18(2), 129140.

차병열, 김병엽, 오성우. 2001. 제주도 연안 정치망 어획량 변 동과 어기. 한국어류학회지, 13(3), 210-219.

차병열, 장대수, 김병엽. 2004. 제주도 함덕 연안의 정치망 어 획량 변동. 한국수산학회지, 37(1), 65-72.

해양수산부. 2002. 통영해역의 바다목장화 개발 연구 용역사 업 보고서. BSPM114-00-1424-7. 783 p.

해양수산부. 2003. 동·서 - 제주형 바다목장개발 후보지 선정 을 위한 기초조사 연구용역. BSPM177-00-1497-3. 314 p.

해양수산부. 2006. 전남 다도해형 바다목장화 개발 연구용역 보고서. BSPM35300-1745-3. 640 p.

해양수산부. 2007. 동-서-제주해역 바다목장화 개발 연구용 역. BSPM42400-1897-3.

허성회, 안용락. 2000. 가덕도 주변 해역 어류의 종조성과 계 절 변동 1. 소형 기선저인망에 의해 채집된 어류. 한국수 산학회지, 33(4), 288-301.

Abad, R., J. Miquel, M. Iglesias, and F. Alvarez. 1998. Acoustic estimation of abundance and distribution of sardine in the northwestern Mediterranean. Fish. Res., 34, 239-245.

Benoit-Bird, K.J., W.W.L. Au, C.D. Kelley, and C. Taylor. 2003. Acoustic backscattering by deepwater fish measured in situ from a manned submersible. Deep-Sea Res. I, 50, 221-229.
BioSonics. 2005. X-series echosounder and visual acquisition 5.0 user guide. BioSonics Inc., Seattle.

Diachok, O., B. Liorzou, and C. Scalabrin. 2001. Estimation of the number density of fish from resonance absorptivity and echo sounder data. ICES J. Mar. Sci., 58, 137-153.

Doray, M., E. Josse, P. Gervain, L. Reynal, and J. Chantrel. 2006. Acoustic characterization of pelagic fish aggregations around moored fish aggregating devices in Martinique (Lesser Antilles). Fish. Res., 82, 162-175.

Everson, I., M. Bravington, and C. Goss. 1996. A combined acoustic and trawl survey for efficiently estimating fish abundance. Fish. Res., 26, 75-91.

Foote, K.G. 1987. Fish target strength for use in echo integrator surveys. J. Acoust. Soc. Am., 82(3), 981-987.

Hewitt, R.P. and D.A. Demer. 1993. Dispersion and abundance of Antarctic Krill in the vicinity of Elephant Island in the 1992 austral summer, Mar. Ecol. Prog. Ser., 99, 29-39.

Jolly, GM. and I. Hampton. 1990. A stratified random transect design for acoustic surveys of fish stocks. Can. J. Fish. Aquat. Sci., 47, 1282-1291.

Kang, D.H. and D.J. Hwang. 2003. Ex situ target strength of rockfish (Sebastes schlegeli) and red seabream (Pagrus major) in the Northwest Pacific. ICES J. Mar. Sci., 60, 538-543.

MacLennan, D.N. and E.J. Simmonds. 1992. Fisheries Acoustics. Chapman \& Hall, London. 325 p.

McClatchie, S., G.J. Macaulay, and R.F. Coombs. 2003. A requiem for the use $20 \log _{10}$ Length for acoustic target strength with special reference to deep-sea fishes. ICES J. Mar. Sci., 60, 419-428.

Ohshimo, S. 2004. Spatial distribution and biomass of pelagic fish in the East China Sea in summer, based on acoustic surveys from 1997 to 2001. Fish. Sci., 70, 389400.

Pang, I.C., H.K. Rho, and T.H. Kim. 1992. Seasonal variations of water mass distributions and their causes in the Yellow Sea, the East China Sea and the adjacent seas of Cheju Island. Bull. Korean Fish. Soc., 25, 151-163.

Reid, D., C. Scalabrin, P. Petitgas, J. Masse, R. Aukland, P. Carrera, and S. Georgakarakos. 2000. Standard protocols for the analysis of school based data from echo sounder surveys. Fish. Res., 47, 125-136.

Simmonds, E.J. and D.N. MacLennan. 2005. Fisheries Acoustics, 2nd ed. Blackwell Science Ltd., Oxford. 437 p. SonarData. 2000. SonarData EchoView User Guide. SonarData Tasmania Pty. Ltd. 